\title{
Combining Macroeconomic Stability and Micro-based Growth: The South East Asia/Asia Pacific experience
}

\section{Ahmed M. Khalid*}

\begin{abstract}
Macroeconomic growth and stability are two of the major benefits of financial development, though there are differences in the literature on the channels through which this growth and stability can be achieved. In recent years, a number of emerging economies experienced phenomenal growth. At a micro level, one needs to understand why and how financial deepening could bring changes in economic agents' behavior leading to an impact on the saving-investment relationship. At the macro level, financial development, integration and globalization could be possible channels to growth. The purpose of this paper is two-fold. First, we provide a comprehensive discussion of the theoretical and empirical literature on the role of important micro- and macro-policy variables in achieving macroeconomic stability with reference to Southeast Asia. Second, we present new empirical evidence using data from a selected sample of countries from the Asia Pacific region on the links between financial integration, trade integration and growth.
\end{abstract}

Keywords: Macroeconomic stability; financial development; economic integration; financial inclusiveness; fixed-effect; Granger causality.

JEL Classification: E61, F02, F15, F43, F63, C33.

\section{Introduction}

A stable macroeconomic system allows individuals, businesses and the government to plan more effectively for the future, increases investment, and enhances productivity. Growth-promoting policies play an important role in shaping the vulnerability to and resilience of an economy facing macroeconomic shocks. These include monetary and budgetary policies, labor and product market policies, and fiscal policies. As many crises are linked to financial sector shocks, financial stability is considered important for macroeconomic stability. ${ }^{1}$

\footnotetext{
* Professor, Universiti Brunei Darussalam and Bond University, Australia.

Note: The author thanks the Lahore School of Economics for the support provided to participate at the conference. Usual disclaimer applies.

${ }^{1}$ See García-Herrero and Wooldrige (2007) for more detailed discussion on this.
} 
A stable macroeconomic system is one in which financial intermediaries, markets, and market infrastructure facilitate the smooth flow of funds between savers and investors and, by doing so, help promote growth in economic activity. In addition, a resilient financial system is one in which there are well developed crisis management arrangements for handling distressed financial institutions in such a way that public confidence in the financial system is not undermined. Financial integration is a phenomenon in which financial markets in regional and/or global economies are closely linked together.

The relationship between macroeconomic stability and microbased growth is a long debated issue. This debate takes a central stage in the context of the experience in the strong economic performance of the Southeast Asian economies since the 1980s. Researchers have debated if such growth is through macroeconomic policies or microeconomic initiatives. Obviously, the benefits of well-structured policies of financial development, financial integration and openness played an important role in the growth performance of the region. The macro-financial linkages through financial integration also increases the importance of supervisory authorities in redefining risk exposures, designing appropriate risk measures and implementing adequate mechanisms to monitor the enforcement of these measures. Hence, the micro-based initiatives such as institutional reforms, restructuring of laws and rights of ownership, and creation of investment friendly environments played an important role in the success of the Asian economies.

Financial integration has been a priority item on the agenda of Asian policymakers since the 1980s. While the 1997 Asian financial crisis was a setback to the growth of the region, it turned out to be a temporary shock and by 2000, most of the countries moved back to their original growth path. In fact, the 1997 Asian financial crisis did not hinder the process of financial reforms and integration in the Southeast Asian region. Rather, as highlighted in the Chiang Mai Initiative (CMI), the 1997 crisis served as a driving force leading to greater regional financial integration in Asia as a means of ensuring financial stability and promoting economic growth. Cross-border holdings among Asian countries are significant in many cases and have increased over the last decade. In addition, Asian countries hold a significantly large share of their overall equity and debt portfolios as investments within the geographical boundaries of Asia.

Besides East Asia, a number of emerging economies experienced phenomenal growth in recent years. For instance, the Indian economy 
enjoyed 7.3 percent growth during 2014-15 as compared to and average of 4.6 percent in emerging markets and only 3.4 percent in the global economy. The record of China is no different, although the economy has recently slowed down. Researchers have focused on the channels through which some of the Asian countries have achieved this stable growth. At the micro level, one needs to understand why and how financial deepening could bring changes in economic agents' behavior leading to an impact on the saving-investment relationship. There is also a need to discuss the importance and role of the supervisory authorities in redefining risk exposures, designing appropriate risk measures, and implementing adequate mechanisms to monitor the enforcement of these measures. On the macro level, financial development, integration, and globalization are possible growth channels and need further assessment.

Table 1 presents a comparison of the growth during the period 1990-2000 (early phase of financial development and reforms) and 20002016 (middle and later phase of financial development, reforms, and integration) for a sample of Asia-Pacific countries. Table 1 shows that more open and integrated countries did not have significant change in their average growth between the two periods. On the other hand, Malaysia experienced a decline from 7 percent average growth in the first period to 4.9 percent average growth in the second period. Singapore and South Korea also experienced a significant decline. Growth did not significantly slow down in the cases of Australia, China, Japan, New Zealand, Thailand and Vietnam. However, countries which implemented economic reforms in the mid- to late-1990s enjoyed higher growth in the later period (20002016). For instance, average growth in Bangladesh increased from 4.7 percent in the first period to 6 percent in the second. This pattern of growth is similar in other countries including India, Indonesia, and Philippines. No significant change in growth is observed in the case of Pakistan where average growth remained low. This may be due to political instability and the security situation faced by the country during the second period. 
Table 1: Per Capital GDP Growth

\begin{tabular}{lcc}
\hline Country & $\mathbf{1 9 9 0 - 2 0 0 0}$ & $\mathbf{2 0 0 0 - 2 0 1 6}$ \\
\hline Australia & 3.6 & 3.0 \\
Bangladesh & 4.7 & 6.0 \\
China & 10.6 & 9.9 \\
India & 6.0 & 7.5 \\
Indonesia & 3.9 & 5.5 \\
Japan & 1.3 & 0.7 \\
Malaysia & 7.0 & 4.9 \\
New Zealand & 3.4 & 2.3 \\
Pakistan & 3.8 & 4.2 \\
Philippines & 3.3 & 5.2 \\
Singapore & 7.2 & 5.8 \\
South Korea & 6.6 & 3.8 \\
Sri Lanka & 5.3 & 6.0 \\
Thailand & 4.1 & 3.9 \\
Vietnam & 7.9 & 6.4 \\
\hline
\end{tabular}

Source: World Development Indicators; http://wdi.worldbank.org/table/4.1; retrieved on 27 July 2017.

The aim of this paper is to further explore these issues in the context of the East Asia and Pacific region. The purpose of this paper is two-fold. First, we plan to provide a comprehensive discussion of the theoretical and empirical literature on important micro- and macro-policy variables focused on macroeconomic stability with reference to Southeast Asia. The discussion will focus on the interdependency between micro- and macrofinancial measures to achieve sustainable growth. Second, we show empirical evidence of the link between financial development and integration, openness, and economic growth using data from a sample of countries from the Asia Pacific region. Key indicators from the financial and real sector are be used to assess macroeconomic stability.

\section{Macro and Financial Stability - A Look at Literature}

On the macro-level, researchers have emphasized the role and importance of macroeconomic variables in achieving sustainable growth. Monetary and fiscal policies as well as real exchange rate stability are considered to be means of economic expansion but cannot guarantee output stability or prevent the economy from facing external shocks. Kydland and Prescott (1977) argue that achieving output stability at the expense of inflation and real exchange rate stability or a viable fiscal policy is not good macroeconomic management. Bleaney (1996) argued that 
macroeconomic instability may impact investment through increased uncertainty about the returns on investment. Rodrik (1991) suggested that macroeconomic instability may lead to political instability and hence impact the investment environment of a country.

Researchers have also identified a number of channels through which macroeconomic stability and sustainable growth can be achieved. Levine and Renelt (1992) believe that the even though the empirical evidence on the correlation between investment and growth is generally consistent in the literature, the causal relationship is not well defined. Bleaney (1996) used a sample of 41 developing countries and found some evidence that measures of policy-induced macroeconomic instability are negatively associated with growth. Ulvedal and Mehlum (2013) suggest that policies such as the implementation of an open international trade regime, the adoption of national innovation policies, well-functioning factor markets, and an investor-friendly legal and regulatory environment could impact economic growth.

Rodrik (1999) argues that institutions play an important role in achieving stable and sustainable growth and that a lack of coordination among institutions and policymakers makes it difficult to implement adjustment policies to deal with external shocks. Using a sample of 101 developed and developing countries, Fischer (1993) found a negative relationship between inflation, the government budget deficit and economic growth. Kormendi and Meguire (1985) found empirical evidence suggesting that money supply changes may adversely affect economic growth. Other researchers have emphasized the importance of factors like institutions, culture and geography in determining growth rates (Acemoglu, 2009).

The literature has also looked at the relationship between openness or trade orientation and economic growth, though there is no consensus on whether outward orientation leads to higher growth though the evidence implies that openness helps bring in foreign capital as well as new technology leading to an increase in total factor productivity.

Huang and Wajid (2002) suggests a three-way approach to growth. They suggest (i) a comprehensive assessment of financial sector vulnerabilities and development needs; (ii) strengthening the monitoring and analysis of the financial sector, developing guidelines, and promoting transparency and integrity; and (iii) building strong institutions. Volz (2013) also suggests that financial integration requires rigorous regional 
institutional building to ensure effective monitoring and surveillance. Borensztein and Loungani (2011) observed that Asian financial systems are more financially integrated with global financial markets as compared to regional neighbors. They also noted that cross-border holdings among Asian countries are significant in many cases and have increased over the last decade.

\section{Macro and Financial Stability - Asia-Pacific Experience}

An important step in achieving financial stability in the ASEAN countries is the enhancement of monetary and financial cooperation between countries including surveillance agreements, financial safety nets and systems to prevent, manage and resolve crises. These steps along with measures under the "New Financial Architecture" such as improving information flows on risk assessment, advancing regional financial infrastructure and capacity building, and providing a regional forum to voice key international developments are all aimed at providing regional financial stability.

While research shows the interdependency between financial stability, integration, and development, the recent EU crisis also exposed the problems such interdependency. A highly integrated and developed financial system does not always and necessarily strengthen financial stability since financial integration can also increase the exposure to more vulnerabilities and systematic risks. The experience of Australia and Asian markets during the 2008 global financial crisis (GFC) reinforces the importance of efficient supervision, gradual development of innovative securitization techniques, and appropriate incentive structures. If we analyze the case of Australia (as well as East Asia) during the GFC, we do not see Australia and East Asia experiencing the same negative impacts of the crisis as did Europe. It is believed that the former group escaped the crisis because of better monitoring and supervision of the financial system. Hence, there is a case for financial integration with prudential supervision. The lessons learnt from the GFC suggest that the European crisis was the consequence of many factors including the fact that supervisory practices and regulatory frameworks did not keep up with the rapid transformation of the financial system. Part of this is due to the introduction of complex financial products such as collateralized debt obligations (CDOs). On the other hand, the ASEAN economies took major steps towards financial cooperation and achieving financial stability in the post-1997 financial crisis period and focused their new financial architecture on crisis prevention and management. 
The literature on monetary policy suggests a number of transmission channels for monetary policy to impact the real sector. The underlying assumption in this transmission mechanism is existence of a sound and well-supervised banking system. However, the last two decades have witnessed rapid and unprecedented development in credit intermediation mainly outside the usual banking system which has led to the movement of funds to unregulated financial intermediaries which has in turn increased risk exposure. One example of this is that, according to some estimates, unregulated financial intermediaries provide up to 80 percent of real estate financing in some countries. These developments have lead the Basel Committee and Financial Stability Board to recommend appropriate regulatory reforms and monitoring systems. For instance, the ASEAN countries have focused on regional macroeconomic and financial stability and a number of groups were established to achieve this goal. Kawai (2012) suggested establishing an Asian Financial Stability Board as a sub-regional forum similar to the Financial Stability Board global forum. Borensztein and Loungani (2010) found evidence supporting the hypothesis of increased financial integration in East Asia using data for equity returns and interest rates.

Table 2 (below) presents the financial development scores published by World Bank (2013) for a sample of Asia-Pacific countries. The composite score included a number of factors assessing financial sector development. Although the overall scores vary from 5.31 (Hong Kong) to 2.92 (Vietnam), the individual categories do not follow the same pattern. For instance, Singapore is ranked highest in institutional environment (6.24), business environment (6.03), financial stability (5.67) and financial markets (5.11) but has a low score on banking and financial services (4.78, ranked similar to Malaysia), non-bank financial services (3.44, below China) and financial access (4.45, ranked $\left.3^{\text {rd }}\right)$. Similarly, Vietnam, which is ranked lowest overall in this sample scored better in banking and financial services and financial access. 
Table 2: Financial Development Scores

\begin{tabular}{|c|c|c|c|c|c|c|c|c|}
\hline Country & Overall & Institutional & Business & Financial & Banking & Non- & Financial & Financial \\
\hline & & Environment $\mathrm{B}$ & invironment & Stability & Financial & Banking & Markets & Access \\
\hline & & & & & Services & Financial & & \\
\hline & & & & & & & & \\
\hline Hong Kong & 5.31 & 5.77 & 6.03 & 5.35 & 6.15 & 3.76 & 5.04 & 5.08 \\
\hline Singapore & 5.1 & 6.24 & 6.03 & 5.67 & 4.78 & 3.44 & 5.11 & 4.45 \\
\hline Australia & 5.01 & 5.48 & 5.6 & 5.26 & 5.04 & 4.35 & 4.37 & 5 \\
\hline Japan & 4.9 & 5.58 & 5.27 & 4.93 & 5.69 & 4.32 & 4.71 & 3.81 \\
\hline South & 4.42 & 4.18 & 5.41 & 4.08 & 4.37 & 5.04 & 3.78 & 4.06 \\
\hline Korea & & & & & & & & \\
\hline Malaysia & 4.24 & 5.12 & 4.85 & 5.24 & 4.71 & 3.23 & 2.71 & 3.79 \\
\hline China & 4 & 4.1 & 3.95 & 4.89 & 4.43 & 4.48 & 2.98 & 3.15 \\
\hline India & 3.63 & 3.42 & 3.61 & 4.67 & 2.61 & 3.24 & 2.99 & 4.90 \\
\hline Thailand & 3.55 & 4.22 & 4.14 & 4.4 & 4.08 & 1.77 & 2.27 & 3.94 \\
\hline Pakistan & 3.46 & 3.09 & 3.48 & 4.11 & 3.91 & 1.73 & 3.58 & 4.33 \\
\hline Philippines & 3.12 & 3.94 & 3.44 & 3.87 & 3.02 & 2.68 & 2.18 & 2.74 \\
\hline Indonesia & 2.95 & 3.46 & 3.49 & 4.4 & 2.82 & 2.38 & 1.39 & 2.69 \\
\hline Vietnam & 2.92 & 3.44 & 3.32 & 3.26 & 3.87 & 1.53 & 1.99 & 3.06 \\
\hline
\end{tabular}

Source: World Economic Forum (2013).

Based on the above discussion, we suggest that macroeconomic stability, financial development and financial integration are closely linked together. This is depicted in Figure 1.

Figure 1: The Three Linkages

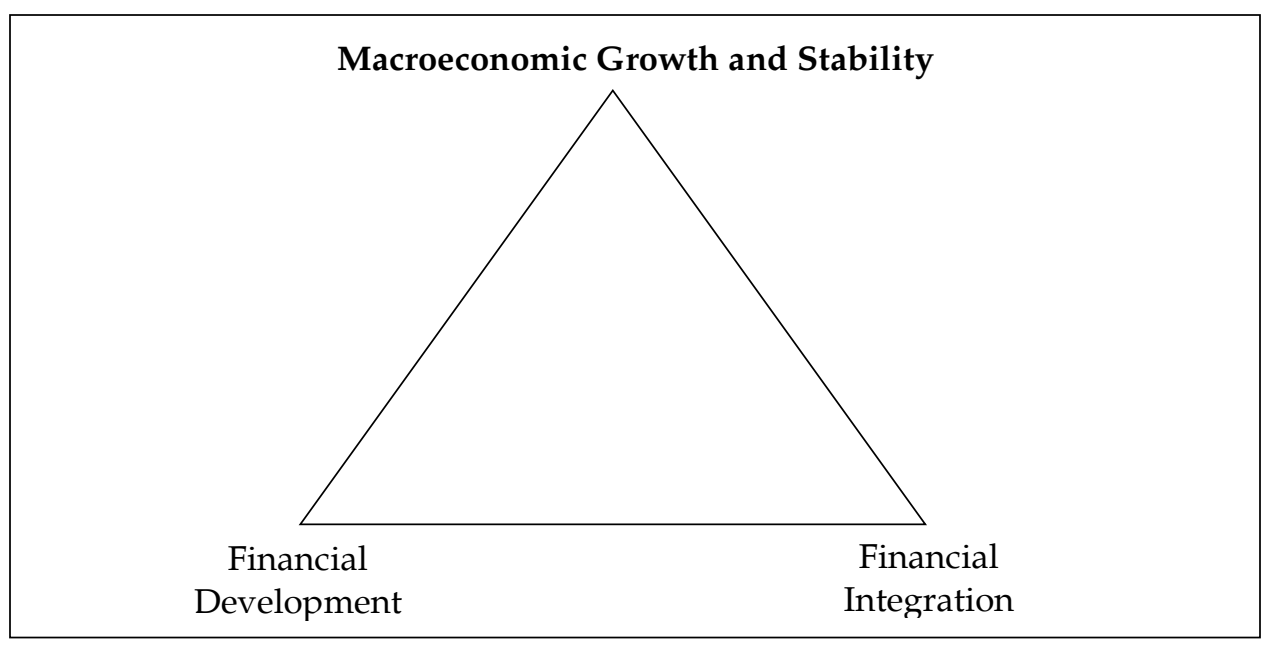

Source: Author 
A number of policy initiatives are needed to connect these three areas and achieve sustainable growth. One important initiative is the understanding of macro-financial linkages (MFLs) which has increased significantly since the GFC. A good understanding of MFLs is believed to be significantly important in promoting sustainable growth. Accordingly, both the real and the financial sectors are considered equally important for the economy. In the credit market, the pro-cyclical behavior of economic agents can be observed through the movement of credit-to-GDP ratio and GDP growth rates. In the capital market, capital flow volatility could be used to find a similar relationship. At the same time, a stable and resilient financial system requires a combination of a prudential policy framework (capital adequacy, market conduct, consumer protection, and safety and soundness) and other policy measures (monetary policy and payments and settlement systems).

Financial inclusion is also a major factor in providing macro and financial stability. As Alfred Hannig, AFI Executive Director, pointed out "...the importance in distinguishing financial deepening and financial inclusion. The traditional approach of measuring deepening does not measure the proportion of the population which has access to formal regulated financial services. Therefore, to measure the health of a country's financial sector, measuring both deepening and inclusion can maximize the benefit for financial sector and macro-economic resilience," (AFI, 2017). Demirguc and Klapper (2012) measured financial inclusion and Figure 2 (adopted from Demirguc and Klapper; 2012) suggests that besides lack of resources, financial literacy is an important factor in low financial inclusion which constrains resources and impedes growth. World Bank (2015) also presents a "financial development barometer" which is based on survey responses from 73 countries. According this barometer, 78 percent of the respondents identify the lack of basic knowledge of financial services as the major barrier to financial access among the poor. This, again, points to the lack of financial inclusion internationally (See Table 3). 


\section{Figure 2: Measuring financial inclusion}

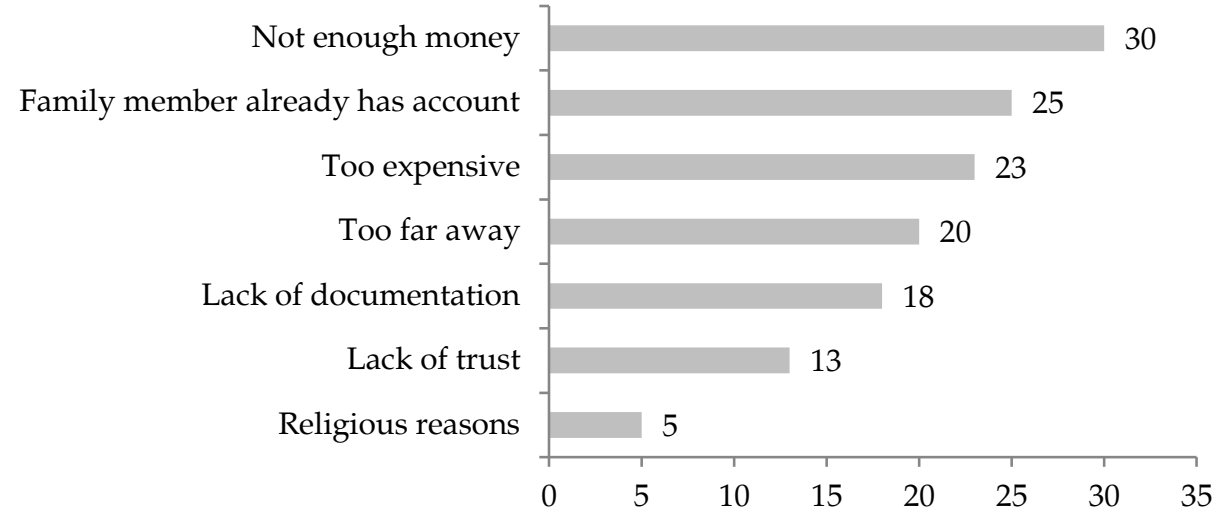

Non-account-holders revorting barrier as a reason for not having an account (\%)

Note: Respondents could choose more than one reason. The data for "not enough money" refer to the percentage of adults who reported only this reason.

Source: Adopted from Demirguc-Kunt and Klapper (2012).

\section{Table 3: Financial Development Barometer - Global views}

\begin{tabular}{|c|c|}
\hline Statements Assessed in the Poll & $\begin{array}{l}\text { Agree? } \\
\text { (\% of all } \\
\text { respondents) }\end{array}$ \\
\hline $\begin{array}{l}\text { "Access to basic financial services is a significant problem for } \\
\text { households in my country." }\end{array}$ & 61 \\
\hline $\begin{array}{l}\text { "Limited access to finance is a significant barrier to the } \\
\text { growth of small enterprises in my country." }\end{array}$ & 76 \\
\hline $\begin{array}{l}\text { "In my country, access to finance has improved significantly } \\
\text { over the last } 5 \text { years." }\end{array}$ & 78 \\
\hline $\begin{array}{l}\text { "Social banking (that is, state banks and targeted lending } \\
\text { programs to poorer segments of the population) is potentially } \\
\text { a useful tool to increase financial access." }\end{array}$ & 80 \\
\hline $\begin{array}{l}\text { "Social banking actually plays an important role in financial } \\
\text { access in my home country." }\end{array}$ & 43 \\
\hline $\begin{array}{l}\text { "The lack of knowledge about basic financial services is a major } \\
\text { barrier to financial access among the poor in my country." }\end{array}$ & 78 \\
\hline
\end{tabular}

Source: Financial Development Barometer, World Bank (2015).

Note: The barometer is an informal global poll of country officials and financial sector experts from 21 developed and 54 developing economies. From 265 polled, 161 responded (61 percent). Results are percentages of "fully agree" and "partially agree" responses out of total responses received. 
The International Monetary Fund (IMF), in a blog under the title "Seven Pillars of Prosperity" (IMF Blog, May 2011), observed seven important operational (policy) and institutional factors contributing to growth. They include (i) reducing the role of the state; (ii) generating openness to new domestic and foreign firms; (iii) a competitive and efficient banking sector; (iv) governance and quality of institutions; (v) improvements in the business environment; (vi) improvements in transport and communications; and (vii) improvements in regional trade and investment links.

\section{Empirical Evidence}

To further understand the relationship between growth and macroeconomic stability in the Asia-Pacific context, we provide some empirical results using a sample of countries from the Asia-Pacific region. The empirical estimation focuses on these two relationships:

1) The role of important macroeconomic variables in determining economic growth

2) The causal relationship between certain indicators of financial and trade integration and growth

The underlying model with fixed effects takes the form:

$g_{i t}=\beta_{0}+\beta_{1}$ FDI $_{i t}+\beta_{2} \mathrm{GFCF}_{i t}+\beta_{3}$ Trade $_{i t}+\beta_{3}$ controls $_{i t}+\eta_{i}+\theta_{t}+\varepsilon_{i t}$

where $\mathrm{g}_{i t}$ is economic growth measured by growth of the real GDP in country $i$ at time $t . \eta_{\mathrm{i}}$ is a country-specific fixed effect, $\theta_{\mathrm{t}}$ is a time effect and $\varepsilon_{\mathrm{it}}$ is a multivariate normally distributed random disturbance.

A fixed effects model, rather than a random effects model is estimated, as the $\eta_{i}$ 's are likely to represent omitted country-specific characteristics which are correlated with other explanatory variables. We use three policy variables. GFCF, FDI and Trade and a set of control variables (INF, GE, Pop and PrCredit).

where,

$\mathrm{g}_{\mathrm{t}}$ : real per capita GDP growth

FDI: ratio of FDI to GDP

GFCF: ratio of gross fixed capital formation to GDP 
Trade: ratio of total trade to GDP

INF: inflation

GE: ratio of government expenditure to GDP

Pop: growth rate of population

PrCredit: ratio of private credit to GDP

The analysis follows two different approaches. First, to avoid endogeneity (as well as small sample) issues, we estimate a fixed effect model for pooled data for the sample of East Asian. Then, we move on to South Asia, and we estimate the same model for a sample of South Asian countries. Second, we use Granger causality tests to investigate causal relationships between the variables of interest.

The data used in the empirical analysis spans 25 years (1989-2013). We use two samples: Sample 1 consists of East-Asian economies (China, Indonesia, Japan, Malaysia, Philippines, Singapore, South Korea and Thailand) while Sample 2 includes South Asian economies (Bangladesh, India, Pakistan and Sri Lanka). The variables used in the estimations are in logs.

The results of the first empirical tests are reported in Table 4. Model 1 excludes the trade-to-GDP ratio while Model 2 includes it. The results suggest that domestic investment is an important determinant of growth in both samples. Similarly, growth is also affected by changes in population (Pop) which is consistent with the predictions of the Solow model. ${ }^{2}$ Although trade does not seem to play any significant role in Sample 1, it negatively affects growth in Sample 2. This could be due to the heavy oil-dependence of countries in South Asian region.

Finally, we perform tests of Granger causality. These results are reported in Table 5. The empirical results show that growth Granger causes domestic investment (GFCF) while the reverse is true in the case of Indonesia. FDI Granger causes growth in the case of Malaysia. In the case of the Philippines, growth is Granger caused by trade. For Singapore, GFCF Granger causes growth and growth Granger causes FDI. This means

\footnotetext{
${ }^{2}$ As an alternative, we use the following model for individual Asian countries. $\mathrm{g}_{\mathrm{t}}=\beta_{0}+\beta_{1} \mathrm{FDI}_{\mathrm{t}}+\beta_{2} \mathrm{GFCF}_{\mathrm{t}}+\beta_{3}$ Trade $_{\mathrm{t}}+\beta_{4}$ controls $_{\mathrm{t}}+\mathrm{e}_{\mathrm{t}}$
}

The results presented in Appendix Table A have low power. These results reveal that for China and Thailand all three policy variables are important determinants of growth. Both domestic and foreign direct investment are important in case of Malaysia. In case of Philippines and South Korea, only domestic investment is significant while for Indonesia and Singapore, FDI determines growth. 
that domestic investment is needed to accelerate growth and then attract FDI. In the case of South Korea, economic growth is needed to promote trade whereas the reverse is true for Bangladesh and India. In the case of Pakistan, growth is Granger caused by both GFCF and trade while trade also Granger causes growth. No relationship for the variables under consideration was found for Thailand and Sri Lanka.

Table 4: Determinants of Growth

Dependent Variable: $g_{i t}$

\begin{tabular}{lcccc}
\hline \multirow{2}{*}{ Variables } & \multicolumn{2}{c}{ Sample 1 } & \multicolumn{2}{c}{ Sample 2 } \\
\cline { 2 - 5 } Model 1 & Model 2 & Model 1 & Model 2 \\
\hline RGDP (-1) & 0.0481 & 0.0478 & 0.0170 & -0.0103 \\
IFDI & $(0.44)$ & $(0.44)$ & $(0.15)$ & $(-0.08)$ \\
GFCF & 0.462 & 0.460 & 0.204 & 0.289 \\
& $(1.06)$ & $(1.03)$ & $(1.58)$ & $(1.42)$ \\
ITrade & $0.185^{* * *}$ & $0.185^{* * *}$ & $0.216^{* *}$ & $0.278^{* *}$ \\
& $(2.00)$ & $(1.91)$ & $(3.59)$ & $(3.84)$ \\
INF & & 0.0427 & & $-1.379^{* *}$ \\
& & $(0.03)$ & & $(-3.27)$ \\
GE & -0.0386 & -0.0386 & -0.00413 & -0.00950 \\
& $(-0.28)$ & $(-0.28)$ & $(-0.09)$ & $(-0.20)$ \\
Pop & -0.148 & -0.149 & -0.0530 & -0.0317 \\
IPrCredit & $(-0.67)$ & $(-0.62)$ & $(-0.82)$ & $(-0.50)$ \\
& $-1.524^{*}$ & $-1.523^{*}$ & -0.856 & -0.967 \\
Constant & $(-5.41)$ & $(-5.85)$ & $(-2.03)$ & $(-2.25)$ \\
& -3.643 & -3.653 & -0.286 & -0.220 \\
Observations & $(-1.89)$ & $(-1.77)$ & $(-0.50)$ & $(-0.50)$ \\
\hline
\end{tabular}

Source: Author's estimation

Notes: ${ }^{*}, * *$ and ${ }^{* * *}$ indicate significance level at $1 \%, 5 \%$ and $10 \%$ respectively.

Sample 1: China, Indonesia, Japan, Malaysia, Philippines, Singapore, South Korea and Thailand Sample 2: Bangladesh, India, Pakistan and Sri Lanka 
Table 5: Granger Causality Test

\begin{tabular}{lll}
\hline Country & To GDP & From GDP \\
\hline China & None & RGDP $\rightarrow$ GFCF \\
Indonesia & GFCF $\rightarrow$ RGDP & \\
Malaysia & FDI $\rightarrow$ RGDP & \\
Philippines & Trade $\rightarrow$ RGDP & \\
Singapore & GFCF $\rightarrow$ RGDP & RGDP $\rightarrow$ FDI \\
South Korea & None & RGDP $\rightarrow$ Trade \\
Thailand & None & None \\
Bangladesh & Trade $\rightarrow$ RGDP & None \\
India & Trade $\rightarrow$ RGDP & \\
Pakistan & GFCF $\rightarrow$ RGDP & RGDP $\rightarrow$ Trade \\
Sri Lanka & Trade $\rightarrow$ RGDP & \\
\hline
\end{tabular}

Source: Author's estimation

Notes: ${ }^{*}, * *$, and ${ }^{* * *}$ indicate significance level at $1 \%, 5 \%$ and $10 \%$ respectively.

\section{Concluding Remarks:}

An attempt is made in this paper to provide a detailed discussion on macroeconomic stability and micro-based growth in the context of the Asia-Pacific. Although there are a number of different micro- and macroeconomic factors determining stable and sustainable economic growth, the discussion in this article focuses on two important channels. First, the article analyzes the broad-based macroeconomic policies leading to economic reforms and integration (including both financial and trade integration). The second focus is on financial inclusion which is essential for the success of macro-policies and is crucial for economic growth.

The interesting question is, whether financial development and economic integration enhances financial and macroeconomic stability. The results discussed in this paper suggest that it does but with certain conditions. These conditions include the use of appropriate policy tools which helps to maintain transparency and market confidence; ensuring the long-term viability of financial institutions in business decisions (through lower agency costs and underlying risk attitude); preventive measures to avoid excessive concentration of risks and leverage to achieve systematic stability; tools to reduce the risk of contagion; prompt corrective actions in case of a forthcoming crisis (crisis management resolution); and good monitoring, assessment and supervision of financial activities leading to financial stability. 
The paper provides both a theoretical framework and empirical evidence for the relationship between financial development, financial integration, and economic growth. The empirical analysis uses pooled data for two samples of East Asian and South Asian countries. The results of the analysis confirm that domestic and foreign investment as well as trade openness are significant determinants of economic growth in most of the sample countries.

Based on the discussion provided and the empirical results presented in this paper, one can draw some lessons and policy implications for countries planning for sustained growth. We suggest that to achieve such growth, countries should embark on policies including reliance on market systems for resource allocation; effective governance and leadership in building consensus (for policy implementation and enforcement); sound economic management (macroeconomic environment); focus on mobilizing savings and investment; resource mobility; and transfer of knowledge and technology (G2G, B2B, and G2B). ${ }^{3}$

${ }^{3} \mathrm{G} 2 \mathrm{G}$ is government to government, B2B is business to business and G2B is government to business. 


\section{References}

Acemoglu, D. (2009). Introduction to Modern Economic Growth. New Jersey: Princeton University Press.

Alliance for Financial Inclusion (AFI) (2017). Financial inclusion necessary to ensure financial stability and macro-economic resilience. Published on AFI on 31 May 2017, http://www.afiglobal.org/news/2017/05/financial-inclusion-necessary-ensurefinancial-stability-and-macro-economic-resilience. Retrieved on 27 July 2017.

Bleaney, M.F. (1996). Macroeconomic stability, investment and growth in developing countries. Journal of Development Economics, 48, 461-477.

Borensztein, E. and Loungani, P. (2011). Asian financial integration: Trends and interpretations, IMF Working Paper, WP/11/4, January.

Creel, J.H. and Labondance, F. (2013). Microeconomic financial stability and economic performance in Europe. FESSUD Research Project, Amsterdam.

Demirguc-Kunt. A and Klapper, L. (2012). Measuring financial inclusion: The global findex database. Policy Research Working Paper number WPS6025, The World Bank, Washington D C. April (https://doi.org/10.1596/1813-9450-6025).

Fischer, S. (1993). The role of macroeconomic factors in growth. Journal of Monetary Economics, 32 (3), 485-512.

García-Herrero, A. and Wooldrige, P. (2007). Global and regional financial integration: progress in emerging markets. BIS Quarterly Review, Bank of International Settlement, September.

Huang, H. and Wajid, S.K. (2002). Financial stability in the world of global finance. Finance and Development, International Monetary Fund, 39(1), March.

Kormendi, R.C. and Meguire, P.G. (1985). Macroeconomic determinants of growth: cross-country evidence. Journal of Monetary Economics, 16 (2), 141-163. 
Kydland, F.E. and Prescott, E.C. (1977). Rules rather than discretion: The inconsistency of optimal plans. The Journal of Political Economy, 473491.

Levine, R. and Renelt, D. (1992). A sensitivity analysis of cross-country growth regressions. The American Economic Review, 942-963.

Rodrik, D. (1991). Policy uncertainty and private investment in developing countries. Journal of Development Economics, 36 (2), 229-242.

Rodrik, D. (1999). Where did all the growth go? External shocks, social conflict, and growth collapses. Journal of Economic Growth, 4 (4), 385-412.

Ulvedal, P.B (2013). Macroeconomic stability and economic growth in developing countries. Master of Philosophy in Economics Department of Economics, University of Oslo.

Ulrich Volz, (2013). Lessons of the European crisis for regional monetary and financial integration in East Asia. Asia Europe Journal, Springer, 11(4), 355-376.

World Bank (2013). World Economic Forum [http://economics.ucsc.edu/research/downloads/Kaur_Singh_Fi nancialIntegration_Oct2013.pdf]. 


\section{Appendix}

Table A: Individual Country Regression

\begin{tabular}{lccc}
\hline $\begin{array}{l}\text { Countries/ Policy } \\
\text { Variables }\end{array}$ & GFCF & lFDI & lTrade \\
\hline China & $0.501^{* * *}$ & $2.410^{* *}$ & $5.322^{* *}$ \\
& $(1.81)$ & $(2.14)$ & $(2.19)$ \\
Indonesia & 0.220 & $0.924^{* * *}$ & 6.463 \\
& $(1.01)$ & $(1.76)$ & $(0.86)$ \\
Malaysia & $0.280^{* *}$ & $2.742^{*}$ & -0.482 \\
& $(2.18)$ & $(3.12)$ & $(-0.05)$ \\
Philippines & $0.923^{*}$ & 0.460 & -0.439 \\
& $(2.82)$ & $(0.76)$ & $(-0.15)$ \\
Singapore & -0.472 & $4.719^{* *}$ & -10.88 \\
& $(-1.27)$ & $(2.15)$ & $(-0.64)$ \\
South Korea & $0.799^{*}$ & -2.539 & -7.495 \\
& $(3.88)$ & $(-1.67)$ & $(-0.87)$ \\
Thailand & $0.559^{*}$ & $-3.885^{* *}$ & $-25.74^{*}$ \\
& $(5.32$ & $(-2.58)$ & $(-3.23)$ \\
\hline
\end{tabular}

Source: Author's estimation

Notes: ${ }^{*}, * *$, and ${ }^{* * *}$ indicate significance level at $1 \%, 5 \%$ and $10 \%$ respectively. 